\title{
Problems with serological diagnosis of Toxoplasma gondii infections in heart transplant recipients
}

\author{
T G WREGHITT,* J J GRAY,* A H BALFOUR†
}

From the *Clinical Microbiology and Public Health Laboratory Addenbrooke's Hospital, Cambridge, and the $\dagger$ Toxoplasmosis Unit, Public Health Laboratory, Leeds

SUMMARY Of the first 128 patients to receive either heart or heart and lung transplants at Papworth Hospital, four developed Toxoplasma gondii infections acquired from the donor heart and two died. Six patients had passively acquired $T$ gondii antibody as a result of blood transfusions around the time of transplantation. Eight patients developed antibodies against $T$ gondii, which were detectable by changes in the latex agglutination test titres but not by those of the dye test. These false positive latex agglutination reactions occurred simultaneously with cytomegalovirus infection and were associated with the IgM serum fraction in the patients' sera. These reactions were not associated with cytomegalovirus specific IgM, Paul-Bunnell antibody, nor detectable rheumatoid factor. These findings emphasise the need for $T$ gondii dye test confirmation of latex agglutination test titre rises in heart transplant recipients.

Toxoplasma gondii infection is one of the major complications associated with heart transplantation. The most common route of infection is via the donor heart, when a seronegative recipient receives a heart from a seropositive donor. ${ }^{12}$ Reactivation of latent infection has also been shown to take place as a result of the immunosuppressive regimen associated with heart transplantation. ${ }^{3}$

In Cambridge $T$ gondii infections are diagnosed initially by a latex agglutination test ${ }^{4}$ (Toxoreagent, Eiken Chemical Company) and are confirmed by the dye and haemagglutination tests and an ELISA for specific IgM. Primary $T$ gondii infection is characterised serologically by a rise in latex agglutination, dye and haemagglutination test titres, and the presence of $T$ gondii specific IgM. We noted, however, that in several patients there was a rise in the latex agglutination titre unconfirmed by the other tests. In this study we examine the reasons for this finding.

\section{Material and methods}

Betweeen January 1979 and August 1985123 patients underwent heart and five patients heart and lung transplantations. The first 29 patients received conventional immunosuppression treatment with azathioprine and steroids. The next 82 patients received cyclosporin $\mathrm{A}$ and low dose steroids, while

Accepted for publication 30 April 1986 the remaining 17 patients received cyclosporin $A$ and azathioprine. All patients received a course of horse antithymocyte globulin (ATG). Serum samples were received at weekly intervals during the patients' stay in hospital and monthly thereafter.

TOXOPLASMA LATEX TEST

This test (Toxoreagent, Eiken Chemical Company of Japan, supplied by Diamed Diagnostics Ltd, Merseyside) was performed according to the manufacturer's instructions.

\section{DYE TEST}

The dye test was performed in flat bottomed microtitre plates and read directly using an inverted microscope, as previously described. ${ }^{4}$

HAEMAGGLUTINATION TEST

The indirect haemagglutination test was performed in microtitre plates with $\mathrm{V}$ shaped wells using sensitised turkey erythrocytes. ${ }^{5}$

\section{$\mu$-CAPTURE ELISA FOR DETECTING $T$ GONDII} SPECIFIC IGM

The antibody class capture enzyme linked immunosorbent assay (ELISA) for detecting $T$ gondii specific IgM previously described by Payne et al, ${ }^{6}$ as modified by Balfour and Harford (unpublished data), was used. Results were expressed in enzyme immunoassay units (EIU), using a positive control serum as a reference. 
COMPLEMENT FIXATION TEST FOR DETECTING

ANTIBODY TO CYTOMEGALOVIRUS

This test was performed by overnight fixation in a microtitre system, a modification of the technique described by Bradstreet and Taylor. ${ }^{7}$ Antigen was supplied by the Public Health Laboratory Service Division of Microbiological Reagents and Quality Control (PHLS, DMRQC), Central Public Health Laboratory, Colindale Avenue, London.

\section{$\mu$-CA PTURE ELISA FOR DETECTING}

CYTOMEGALOVIRUS SPECIFIC IGM

The wells of Falcon flexible EIA plates (Becton Dickinson) were coated overnight at $4^{\circ} \mathrm{C}$ with $100 \mu \mathrm{l}$ of DAKO rabbit antihuman IgM (diluted 1/2000 in carbonate and bicarbonate buffer, $\mathrm{pH} 9 \cdot 6$ ). Plates were washed three times (with $0.85 \%$ sodium chloride containing $0.08 \%$ Tween 20 ) and $100 \mu$ l of human serum (diluted $1 / 100$ in phosphate buffered saline and Tween 20) were then added and the plates incubated at $37^{\circ} \mathrm{C}$ for three hours. Serum dilutions were not placed in the top rows of each plate. Reference control sera containing $100,33,10,3.3,1,0.33,0.1$ and 0 arbitrary units of cytomegalovirus specific IgM were included in each assay.

The plates were washed and $100 \mu \mathrm{l}$ of cytomegalovirus complement fixation test antigen (PHLS, DMRQC) (diluted 1/10 in phosphate buffered saline and Tween 20 with $10 \%$ fetal calf serum) were added to each well that had contained serum. The plates were stored at $4^{\circ} \mathrm{C}$ overnight and then washed three times before $100 \mu \mathrm{l}$ of peroxidase conjugated anti cytomegalovirus monoclonal antibody ${ }^{8}$ was added to all wells, except those in the top row. The plates were incubated at $37^{\circ} \mathrm{C}$ for three hours. The dilutions of antigen and conjugate used had been previously determined by chequerboard titrations. The plates were washed three times and $100 \mu \mathrm{l}$ of substrate solution (o-phenylenediamine $(1 \mathrm{mg} / \mathrm{ml})$ and hydrogen peroxide $(0.4 \mu \mathrm{l} / \mathrm{ml})$ in citric acid and phosphate buffer pH5) were added to all wells and the plates incubated for 30 minutes at room temperature, when the reaction was stopped with $25 \mu \mathrm{l} 3 \mathrm{M}$ sulphuric acid. Absorbance was read at $492 \mathrm{~nm}$ in a Titertek Multiskan (Flow Labs Ltd). The top row of wells, coated with antihuman IgM and containing substrate and stop solution, were used to blank the plate. The amount of cytomegalovirus specific IgM in each serum was determined with reference to a standard curve plotted from the results obtained with the reference positive control series.

\section{Results}

Four cardiac transplant recipients with confirmed $T$ gondii infection - that is, seroconversion by lateg

Table 1 Passively acquired $T$ gondii antibodies in sera from six heart transplant patients

\begin{tabular}{|c|c|c|c|c|c|}
\hline \multirow[b]{2}{*}{ Case No } & \multirow[b]{2}{*}{ Days after transplantation } & \multicolumn{4}{|l|}{$T$ gondii } \\
\hline & & $\begin{array}{l}\text { Latex agglutination } \\
\text { test titre }\end{array}$ & Dye test titre & $\begin{array}{l}\text { Haemagglutination } \\
\text { titre }\end{array}$ & $\underset{\text { (units) }}{\text { IgM }}$ \\
\hline 1 & $\begin{array}{l}\text { Pretransplantation } \\
2 \\
44\end{array}$ & $\begin{array}{l}<16 \\
32 \\
<16\end{array}$ & $\begin{array}{l}<8 \\
<8 \\
<8\end{array}$ & $\begin{array}{l}<32 \\
<32 \\
<32\end{array}$ & \} 0 \\
\hline 2 & $\begin{array}{l}\text { Pretransplantation } \\
11\end{array}$ & $\begin{array}{r}<16 \\
\quad 32\end{array}$ & $<8$ & $<32$ & 0 \\
\hline & $\begin{array}{l}11 \\
18 \\
26\end{array}$ & $\begin{array}{r}32 \\
<16\end{array}$ & $\begin{array}{r}16 \\
<8\end{array}$ & $\begin{array}{r}128 \\
<32\end{array}$ & \}$_{0}$ \\
\hline 3 & $\begin{array}{l}\text { Pretransplantation } \\
3 \\
6 \\
13 \\
23 \\
30\end{array}$ & $\begin{array}{r}<16 \\
32 \\
64 \\
16 \\
16 \\
<16\end{array}$ & $\begin{array}{l}<8 \\
64 \\
32 \\
32 \\
<8 \\
<8\end{array}$ & $\begin{array}{r}<32 \\
<32 \\
128 \\
128 \\
64 \\
64\end{array}$ & 0 \\
\hline 4 & $\begin{array}{l}\text { Pretransplantation } \\
18 \\
21 \\
28\end{array}$ & $\begin{array}{r}<16 \\
32 \\
16 \\
16\end{array}$ & $\begin{array}{l}<8 \\
<8 \\
<8 \\
<8\end{array}$ & $\begin{array}{l}<32 \\
<32 \\
32 \\
<32\end{array}$ & 0 \\
\hline & 98 & $<16$ & $<8$ & $<32$ & \\
\hline 5 & $\begin{array}{l}\text { Pretransplantation } \\
3 \\
30\end{array}$ & $\begin{array}{l}<16 \\
32 \\
<16\end{array}$ & $\begin{array}{r}<8 \\
64 \\
<8\end{array}$ & $\begin{array}{r}<32 \\
128 \\
64\end{array}$ & 0 \\
\hline 6 & $\begin{array}{l}\text { Pretransplantation } \\
12 \\
26 \\
33 \\
40\end{array}$ & $\begin{array}{r}<16 \\
16 \\
16 \\
16 \\
<16\end{array}$ & $\begin{array}{l}<8 \\
<8 \\
<8 \\
<8 \\
<8\end{array}$ & $\begin{array}{l}<32 \\
<32 \\
<32 \\
32 \\
<32\end{array}$ & 0 \\
\hline
\end{tabular}


agglutination, dye and haemagglutination tests, and specific IgM in sera taken in the early convalescent phase occurred in this series. These infections have been reported elsewhere. ${ }^{129}$

Six patients were shown to have passively acquired anti-T gondii antibody as a result of receiving blood or blood products around the time of transplantation. Results of serological tests performed on sera taken from these patients showed a transitory rise in latex agglutination antibody detectable until about one month after transplantation (table 1). Some of these sera also showed a transitory rise in dye test or haemagglutination titre, or both.

Eight patients seroconverted to $T$ gondii by latex agglutination (table 2). Sera from only one of these patients, however, showed evidence of antibody production in the other serological tests, with a rise in the haemagglutination test titre, while the dye test titre remained at $<16$. $T$ gondii specific IgM could not be found in sera from any of these patients. In all eight patients seroconversion in the latex agglutination test was noted simultaneously with serological evidence of primary or reactivated cytomegalovirus infection, which occurred between 29 days and four and a half years after transplantation.

By fractioning several of the sera with high nonspecific latex agglutination titres on $15 \%-40 \%(w / v)$ sucrose gradients, it was found that only those frac-

Table $2 T$ gondii and cytomegalovirus antibodies in sera from eight heart transplant patients

\begin{tabular}{|c|c|c|c|c|c|c|c|}
\hline \multirow[b]{2}{*}{ Case No } & \multirow[b]{2}{*}{$\begin{array}{l}\text { Days after } \\
\text { transplantation }\end{array}$} & \multicolumn{4}{|c|}{ Toxoplasma } & \multicolumn{2}{|c|}{ Cytomegalovirus } \\
\hline & & $\begin{array}{l}\text { Latex test } \\
\text { titre }\end{array}$ & $\begin{array}{l}\text { Dye test } \\
\text { titre }\end{array}$ & $\begin{array}{l}\text { Haemagglutination } \\
\text { test titre }\end{array}$ & $\operatorname{Ig} M(E I U)$ & $\begin{array}{l}\text { Complement } \\
\text { fixation test } \\
\text { titre }\end{array}$ & $\begin{array}{l}\text { IgM } \\
\text { (units) }\end{array}$ \\
\hline 7 & $\begin{array}{l}\text { Pretransplantation } \\
25 \\
39 \\
54 \\
70 \\
89 \\
102\end{array}$ & $\begin{array}{r}<16 \\
<16 \\
64 \\
32 \\
16 \\
<16 \\
<16\end{array}$ & $<8$ & \}$<32$ & 0 & $\begin{array}{r}256 \\
256 \\
512 \\
512 \\
1000 \\
4000 \\
2000\end{array}$ & $\begin{array}{l}0 \\
0 \\
0 \cdot 33 \\
0 \cdot 33 \\
1 \cdot 0 \\
1 \cdot 0 \\
0 \cdot 33\end{array}$ \\
\hline 8 & $\begin{array}{l}\text { Pretransplantation } \\
32 \\
38 \\
45 \\
83 \\
97 \\
381 \\
652\end{array}$ & $\begin{array}{r}<16 \\
<16 \\
<16 \\
64 \\
32 \\
16 \\
32 \\
32\end{array}$ & $<8$ & \}$<32$ & 0 & $\begin{array}{r}<8 \\
<8 \\
<8 \\
512 \\
1024 \\
1024 \\
1024 \\
1024\end{array}$ & $\begin{array}{c}0 \\
0 \\
3 \cdot 3 \\
100 \\
100 \\
100 \\
33 \\
10\end{array}$ \\
\hline 9 & $\begin{array}{l}\text { Pretransplantation } \\
48 \\
55 \\
93 \\
121\end{array}$ & $\begin{array}{r}<16 \\
<16 \\
64 \\
16 \\
16\end{array}$ & $<8$ & $<<32$ & 0 & $\begin{array}{l}<8 \\
<8 \\
256 \\
256 \\
256\end{array}$ & $\begin{array}{c}0 \\
3 \cdot 3 \\
100 \\
33 \\
33\end{array}$ \\
\hline 10 & $\begin{array}{l}\text { Pretransplantation } \\
29 \\
36 \\
41 \\
94 \\
123 \\
183\end{array}$ & $\begin{array}{r}<16 \\
<16 \\
<16 \\
16 \\
128 \\
64 \\
16\end{array}$ & $<8$ & \}$<32$ & 0 & $\begin{array}{r}32 \\
32 \\
32 \\
64 \\
512 \\
512 \\
512\end{array}$ & $\begin{array}{l}0 \\
0 \\
0 \cdot 10 \\
0 \cdot 33 \\
3 \cdot 3 \\
1 \cdot 0 \\
0 \cdot 33\end{array}$ \\
\hline 11 & $\begin{array}{l}\text { Pretransplantation } \\
4 \text { years } 81 \text { days } \\
4 \text { years } 172 \text { days } \\
4 \text { years } 181 \text { days } \\
4 \text { years } 187 \text { days } \\
5 \text { years }\end{array}$ & $\begin{aligned}<16 \\
<16 \\
<16 / 16 \\
\quad 64 \\
\quad 64 \\
<16\end{aligned}$ & $<8$ & $<<32$ & 0 & $\begin{array}{r}<8 \\
<8 \\
<8 \\
2000 \\
512 \\
128\end{array}$ & $\begin{array}{c}0 \\
0 \\
3 \cdot 3 \\
100 \\
33 \\
1 \cdot 0\end{array}$ \\
\hline 12 & $\begin{array}{l}\text { Pretransplantation } \\
33 \\
39 \\
91 \\
106 \\
150\end{array}$ & $\begin{array}{r}<16 \\
<16 \\
32 \\
32 \\
32 \\
<16\end{array}$ & $<8$ & $\begin{array}{l}<32 \\
<32 \\
<32 \\
128 \\
256 \\
128\end{array}$ & 0 & $\begin{array}{r}<8 \\
<8 \\
<8 \\
4000 \\
1024 \\
1024\end{array}$ & $\begin{array}{r}0 \\
0 \\
33 \\
100 \\
100 \\
33\end{array}$ \\
\hline 13 & $\begin{array}{l}59 \\
67 \\
77\end{array}$ & $\begin{array}{r}<16 \\
16 \\
16\end{array}$ & $<8$ & \}$<32$ & 0 & $\begin{array}{r}<8 \\
16 \\
256\end{array}$ & $\begin{array}{r}0 \\
33 \\
33\end{array}$ \\
\hline 14 & $\begin{array}{r}35 \\
121 \\
184 \\
359\end{array}$ & $\begin{array}{r}<16 \\
32 \\
>64 \\
>64\end{array}$ & $<8$ & $\{<32$ & 0 & $\begin{array}{r}<8 \\
1024 \\
512 \\
512\end{array}$ & $\begin{array}{l}>0.33 \\
>0.33 \\
<0.33\end{array}$ \\
\hline
\end{tabular}


tions containing IgM gave a reaction in the latex agglutination test. Furthermore, when these fractions were treated with 2-mercaptoethanol before testing, agglutination did not take place. This confirmed that agglutination was due to IgM.

The non-specific seroconversion in the latex agglutination test did not correlate absolutely with the presence of cytomegalovirus specific IgM (table 2). Furthermore, there was no correlation between the latex agglutination test titres and the amount of cytomegalovirus specific IgM (arbitrary units). In five patients the timing of the rises in latex agglutination titre correlated with the appearance of cytomegalovirus specific IgM, but in three it did not.

None of the sera was shown to contain PaulBunnell antibody. Many sera contained rheumatoid factor, as measured in the Rheumowelcotest latex agglutination test (Wellcome Diagnostics). The amount of rheumatoid factor did not correlate with the non-specific latex agglutination test titres. Preadsorbing the sera with Rheumowelcotest latex and aggregated $\mathrm{IgG}$ failed to reduce the non-specific latex agglutination titres. Furthermore, three sera with false positive titres of 64 and 32 in the Eiken latex agglutination test gave a titre of $<16$ in tests using control latex not sensitised with $T$ gondii antigen and coated only with bovine serum albumen.

\section{Discussion}

$T$ gondii is an important cause of morbidity and mortality in heart transplant recipients. While reactivation of latent infection is usually associated with relatively mild symptoms (Wreghitt TG, et al, unpublished observations) death may result, particularly in association with other organisms such as Pneumocystis carinii, cytomegalovirus, and aspergillus. ${ }^{3}$ Primary infection with $T$ gondii, which is most often associated with transmission via the donor organ, ${ }^{12910}$ is almost always fatal, unless treated promptly with anti$T$ gondii chemotherapy. ${ }^{12} 10$

Primary $T$ gondii infections, like cytomegalovirus infections, become clinically apparent in the first six weeks after transplantation. ${ }^{12910}$ Starting appropriate treatment depends on prompt diagnosis of infection. Seroconversion to $T$ gondii can be detected 12-35 days (mean 25 days) after transplantation, while symptoms indicative of $T$ gondii infection are not observed until 20-45 days (mean 36 days) after transplantation. ${ }^{10}$ It is clear, therefore, that accurate serological diagnosis of infection is important in the management of the disease. ${ }^{11}$ In Cambridge latex agglutination is used as the initial test for detecting $T$ gondii seroconversion, confirmation being sought by dye, haemagglutination, and IgM tests. It is therefore important that the latex agglutination test should be a reliable indicator of acute $T$ gondii infection.

Passively acquired $T$ gondii antibody (table 1 ) does not complicate the serological diagnosis of $T$ gondii infection, as it appears immediately after transplantation, usually at low titre, and becomes undetectable within a month of transplantation. On the contrary, non-specific seroconversion by latex agglutination (table 2) could initially lead to an erroneous diagnosis of $T$ gondii infection, when, in fact, the patient would be experiencing cytomegalovirus infection.

The non-specific latex agglutination seroconversion was associated with cytomegalovirus infection (table 2), with most patients experiencing cytomegalovirus infection in the first two months after transplantation. One patient (case 11), however, did not acquire cytomegalovirus infection until four years after transplantation; this was also associated with non-specific latex agglutination seroconversion. All sera taken from this patient before the onset of the cytomegalovirus infection had a latex agglutination titre $<16$. Non-specific latex agglutination titres were associated with primary cytomegalovirus infections (cases 8, 9,11,12, and 13) and cytomegalovirus reactivations (cases 7, 10, and 14). Although all the false positive latex agglutination titres were found with sera taken at the time of acute cytomegalovirus infection, sera from many heart transplant recipien 6 experiencing cytomegalovirus infection did not give non-specific latex agglutination titres.

Our inability to identify the serum component pro ducing the non-specific latex agglutination was disappointing, although we have noted this effect with several batches of Eiken latex reagent. We have shown that it is an IgM antibody associated with some cytomegalovirus infection, because it migrates to the $19 \mathrm{~S}$ IgM fraction in sucrose density gradients and is denatured by 2-mercaptoethanol. It is not, however, cytomegalovirus specific IgM, as the $T$ gondii latex agglutination titres did not correlate with the amount of cytomagalovirus specific IgM in sera (arbitrary units), nor is it Paul-Bunnell antibody, IgM anti-IgG rheumatoid factor antibody, or antibody to latex particles. It differs also from the factors causing false positive results in the IgM-ELISA previously described by Luft et al ${ }^{11}$ and Naot et al. ${ }^{12}$ They used an indirect ELISA for the detection of $T$ gondii IgM in sera from cardiac transplant patients and found non-specific reactions with this assay in sera taken early in the course of transplantation. They showed that this non-specific reaction was caused by the inter- $\omega$ action of antibodies directed against the species of ${ }^{2}$ origin of ATG (rabbit) used as part of the immunosuppressive regimen and rabbit antibody used as a $\mathbb{D}$ reagent in their assay. The patients in our series were given horse ATG. Furthermore, one of our patients 
tested at regular intervals after transplantation acquired primary cytomegalovirus and showed concurrent non-specific latex agglutination titres four and a half years after transplantation and had received ATG only for a short time immediately after transplantation. It is unlikely, therefore, that this false positive reaction was related to ATG antibodies similar to those described in American patients, ${ }^{1112}$ and it would seem much more likely that it is associated in some way with active cytomegalovirus infection.

Now that we are aware of the non-specific latex agglutination titres in association with acute cytomegalovirus infection in heart transplant recipients, the chance of an initial erroneous serological diagnosis of $T$ gondii infection is minimised, and we are continuing to use the Eiken latex test and find it a useful screening test. It is, nevertheless, of paramount importance to have a sensitive test (such as $\mu$-capture ELISA) for the rapid diagnosis of cytomegalovirus infection and to carry out further confirmatory $T$ gondii serological tests.

\section{References}

1 Nagington J, Martin AL. Toxoplasmosis and heart transplantation. Lancet 1983;ii:679.

2 Hakim M, Wreghitt TG, English TAH, Stovin PGI, Cory-Pearce $R$, Wallwork J. Significance of donor transmitted disease in cardiac transplantation. Heart Transplantation 1985;IV:302-6.
3 Stinson EB, Bieber CP, Griepp RB, Clark DA, Shumway NE, Remington JS. Infectious complications after cardiac transplantation in man. Ann Intern Med 1971;74:22-36.

4 Hunter D, Chadwick P, Balfour AH, Bridges JB. Examination of ovine foetal fluid for antibodies to Toxoplasma gondii by the dye test and an indirect immunofluorescence test for specific IgM. Br Vet $J$ 1982;138:29-33.

5 Hunter D, Chadwick P, Balfour AH, Bridges JB. An assessment of a commercially available haemagglutination test for detecting Toxoplasma antibodies in ovine sera. $\mathrm{Br} \mathrm{Vet} J$ 1980;136:339-42.

6 Payne RA, Isaac M, Francis J. Enzyme-linked immunosorbent assay (ELISA) using class capture for the detection of antiToxoplasma IgM. J Clin Pathol 1982;35:892-6.

7 Bradstreet CMP, Taylor CED. Technique of complement-fixation test applicable to the diagnosis of virus diseases. Monthly Bulletin of the Ministry of Health and the Public Health Laboratory Service 1962:21:96-104.

8 Wreghitt TG, Hicks J, Gray JJ, O'Connor C. Development of a competitive enzyme-linked immunosorbent assay for detecing cytomegalovirus antibody. J Med Virol 1986;18:119-29.

9 McGregor CGA, Fleck DG, Nagington J, Stovin PGI, CoryPearce R, English TAH. Disseminated toxoplasmosis in cardiac transplantation. J Clin Pathol 1984;37:74-7.

10 Hakim M, Esmore D, Wreghitt TG, Wallwork J, English TAH. Toxoplasmosis in cardiac transplantation. $\mathrm{Br}$ Med $J$ 1986;292:1108.

11 Luft BJ, Naot Y, Araujo FG, Stunson EB, Remington JS. Primary and reactivated Toxoplasma infection in patients with cardiac transplants. Ann Intern Med 1983;99:27-31.

12 Naot Y, Luft BJ, Remington J. False-positive serological tests in heart transplant recipients. Lancet 1981;ii:590-1.

Requests for reprints to: Dr TG Wreghitt, Public Health Laboratory, Level 6, Addenbrooke's Hospital, Hills Road, Cambridge CB2 2QW, England. 